\title{
Identifikasi Jenis Mangrove Di Kawasan Konservasi Laut Daerah (KKLD) Gili Sulat - Gili Lawang Kabupaten Lombok Timur
}

\author{
Lalu Samsul Rizal \\ Dosen Jurusan Pemanfaatan Sumberdaya Perikanan \\ Universitas 45 Mataram \\ Email : Samsullombok928@mail.com
}

\begin{abstract}
Abstrak. Kawasan Konservasi Laut Daerah (KKLD) Gili Sulat-Gili Lawang sudah berjalan 17 (tujuh belas) tahun, namun pengelolaannya masih belum maksimal terutama pada perlindungan ekosistem mangrove yang ada di dalam kawasan konservasi dan kepedulian masyarakat dalam rangka pengelolaan dan pelestarian fungsi sumberdaya ikan dan biota lainnya. Berdasarkan pertimbangan potensi yang ada di Kawasan Konservasi Laut Daerah (KKLD) Gili Sulat - Gili Lawang dan sekitarnya dengan beberapa ekosistem pesisir laut yang ada, kawasan ini memerlukan sebuah strategi pengelolaan secara optimal dengan memperhatikan kaidah-kaidah berkelanjutan dan perlindungan kelestariannya, khususnya terhadap pengelolaan mangrove. Tujuan penelitian (1) Untuk mengetahui jenis mangrove yang ada di sekitar Kawasan Konservasi Laut Daerah (KKLD) Gili Sulat - Gili Lawang. (2) mengetahui persepsi masyrakat terhadap lahan mangrove (3) mengetahui dampak kerusakan lahan mangrove terhadap biota ikan dan non ikan. Disimpulkan persepsi masyarakat terhadap pelestarian dan pemanfaatan lahan mangrove menunjukkan sangat setuju, namun belum sampai ke tahap aplikasi mengingat tingkat kesadaran dan pendidikan masyarakat tentang pemanfaatan dan pelestarian lahan mangrove sangat rendah. Pemerintah (Dinas Kelautan Perikanan dan Dinas Kehutanan), menunjukkan sikap terhadap pelestarian dan pemanfaatan lahan mangrove sangat setuju namun ditingkat aplikasi peran pemerintah belum terlaksana yang disebabkan karena kepentingan ekonomi dan penegakan hukum yang masih begitu lemah. Struktur vegetasi mangrove didominasi oleh jenis Rizhophora mucronata dan Bruguera sexangula dari famili Rhizoporaceae. Stasiun 1 untuk tingkat pohon, pancang dan anakan didominasi oleh Rhizopora mucronata. Stasiun II untuk tingkat pohon, pancang dan anakan didominasi oleh Rhizophora mucronata dan Bruguera gymnoriza. Stasiun III untuk tingkat pohon, pancang dan semai didominasi oleh jenis Rhizophora mucronata dan Avecinea officinalis. Pada stasiun IV untuk tingkat pohon, pancang dan semai didominasi oleh Rhizopora mucronata dan Bruguera stylosa. Untuk keragaman fauna air yang berasosiasi dengan lahan mangrove jenis ikan dan non ikan yang dominan di tangkap adalah famili siganidae dengan sepesies beronang (siganus $s p$ ).
\end{abstract}

Kata kunci : Mangrove, Persepsi,Keragaman.

Abstract. Land clearing ponds in coastal mangrove village Gili sulat- gili Lawang . Research (1) to determine the perceptions of stakeholders (communities, Government and Employers) (2) determine the vegetation structure of mangrove land (3) determine the impact of mangrove degradation on fish and non-fish biota. Concluded fishing community perceptions towards conservation and land use mangrove exhibit was agreed, but not yet reached the stage of considering applications kesadran level and public education about the use and conservation of mangrove land is very low. Government (Department of Marine Fisheries, Forestry and entrepreneurs), shows the attitude towards the preservation and utilization of mangrove land could not agree more, but the level of application of the role of government and employers have not been implemented due to economic interests and the rule of law is still so weak. The structure is dominated by mangrove vegetation Rizhophoramucronata and Bruguerasexangula of families Rhizoporaceae. Stations 1 to level trees, saplings and seedlings dominated by Rhizophoramucronata. Station II to level trees, saplings and seedlings dominated by 
Rhizophoramucronata and Brugueragymnoriza. Station III to level trees, saplings and seedlings dominated by Rhizophoramucronata and Avecineaofficinalis. At station IV to level trees, saplings and seedlings dominated by Rhizophoramucronata and Bruguerastylosa. For the diversity of aquatic fauna associated with mangrove land good condition and critical fish and non-fish catch was dominant in the family siganidae with sepesiesberonang (Siganussp). For the non-fish catches in the mangrove land good condition and critical for three months in the dominance of the family Portunidae with sepesies crab (Scylla serrata) and crab (Portunuspelagicus).

Keywords: Mangrove, Perception, Diversity.

\section{PENDAHULUAN}

Mangrove di Provinsi Nusa Tenggara Barat (NTB), berdasarkan statistik tahun 1993 dengan metode Citra satelit Landsat memiliki luas sekitar 49.174 ha, yang tersebar di seluruh Pesisir Nusa Tenggara Barat terutama yang berada di daerah teluk ataupun pantai yang terlindung dari hempasan ombak. Kemudian Geisen (1993) dalam (Pramudji, 2000), menyatakan bahwa luas hutan mangrove di kawasan tersebut adalah 4.500 hektar. Hal ini menunjukkan bahwa laju kerusakan hutan mangrove pada kurun waktu 1993-1999 mencapai 28,940 ha, atau dengan kata lain kerusakan hutan mangrove di NTB mencapai 4.823 ha setiap tahunnya. Kondisi yang memprihatinkan ini terus berlanjut dari waktu ke waktu, sampai tahun 2006 dengan luas 18.357 ha. Berdasarkan kajian peta GIS terakhir tahun 2008 hutan mangrove di NTB hanya tersisa $18.098 \mathrm{ha}$, terdiri dari 10.571 ha yang berlokasi di luar kawasan hutan dan 7.526 ha, di dalam kawasan hutan dengan kondisi sekitar $54 \%$ telah mengalami kerusakan. Kondisi yang masih baik dan relatif baik terutama terdapat di dalam kawasan hutan negara dan kawasan yang telah ditetapkan sebagai kawasan konservasi laut daerah (Bappeda, 2010). Kawasan Konservasi Laut Daerah (KKLD) Gili Sulat - Gili Lawang sudah berjalan 17 (tujuh belas) tahun, namun pengelolaannya masih belum maksimal terutama pada perlindungan ekosistem mangrove yang ada di dalam kawasan konservasi dan komitmen masyarakat dalam rangka pengelolaan dan pelestarian fungsi sumberdaya ikan dan biota lainnya. Berdasarkan pertimbangan potensi yang ada di Kawasan Konservasi Laut Daaerah
(KKLD) Gili Sulat - Gili Lawang dan sekitarnya dengan beberapa ekosistem pesisir laut yang ada, khususnya mangrove, maka kawasan ini memerlukan sebuah strategi pengelolaan secara optimal dengan memperhatikan kaidah-kaidah berkelanjutan dan perlindungan kelestariannya, khususnya terhadap mangrove. Kawasan Konservasi Laut Daerah (KKLD) Gili Sulat-Gili Lawang seperti yang tertuang dalam Peraturan Daerah Kabupaten Lombok Timur Nomor 10 Tahun 2006, sudah ditetapkan batasan-batasan zona inti yaitu zona inti I di Gili Lawang dengan titik-titik koordinatnya adalah a) Sebelah Barat Utara $8^{\circ} 16^{\prime} 42^{\prime \prime}$ Lintang Selatan dan $116^{\circ} 41^{\prime} 42,5^{\prime \prime}$ Bujur Timur, b) Sebelah Barat Selatan $8^{\circ} 17 ' 28,6^{\prime \prime}$ Lintang Selatan dan $116^{\circ} 41^{\prime} 15,9^{\prime}$ 'Bujur Timur, c) Sebelah Timur Utara $8^{\circ} 18^{\prime} 27,5^{\prime \prime}$ Lintang Selatan dan $116^{\circ} 43^{\prime} 03,7^{\prime}$ 'Bujur Timur, d) Sebelah Timur Selatan $8^{\circ} 18^{\prime} 41^{\prime \prime}$ Lintang Selatan dan $116^{\circ} 42^{\prime} 34,7$ " Bujur Timur, dan zona inti II terletak di Gili Sulat dengan titik-titik koordinat berada di: a) Sebelah Barat Utara $8^{\circ} 18^{\prime} 34,2$ " Lintang Selatan dan $116^{\circ} 43^{\prime} 12,7^{\prime \prime}$ Bujur Timur, b) Sebelah Barat Selatan $8^{\circ} 18^{\prime} 55,0^{\prime \prime}$ Lintang Selatan dan $116^{\circ} 42^{\prime} 39,3^{\prime \prime}$ Bujur Timur, c) Sebelah Timur Utara $8^{\circ} 20^{\prime} 25,3^{\prime \prime}$ Lintang Selatan dan $116^{\circ} 45^{\prime} 02,7^{\prime \prime}$ Bujur Timur, d) Sebelah Timur Selatan $8^{\circ} 20^{\prime} 53,4^{\prime \prime}$ Lintang Selatan dan $116^{\circ} 44^{\prime} 50,8^{\prime \prime}$ Bujur Timur. Di dalam Zona inti sudah seharusnya diupayakan seminimal mungkin intervensi manusia. Kondisi mangrove di Kawasan Konservasi Laut Daerah (KKLD) Giki Sulat - Gili Lawang terlihat belum mengalami tekanan dari hasil survei lapangan dibeberapa lokasi perairan sekitar mangrove terdapat ekosistem padang lamun dan terumbu 
karang yang tumbuh secara sporadik, kondisi seperti ini merupakan potensi kesuburan perairan didaerah ini, karena ketiga ekosistem tersebut mempunyai produktifitas yang sangat tinggi dan mampu menopang kehidupan berbagai macam biota laut yang ada diperairan tersebut. Namun demikian karena aktifitas masyarakat yang memanfaatkan sumberdaya alam tersebut cenderung hanya memikirkan aspek ekonominya maka dampaknya adalah lahan mangrove di kawasan ini luasannya mencapai 641.630 ha. Aktifitas masyarakat setempat tidak hanya menkonversi mangrove saja, tetapi terumbu karang diperairan ini juga menjadi sasaran bagi masyarakat yang mencari ikan dengan cara pengeboman yang berakibat akan mengancam eksistensi ekosistem diperairan tersebut. Jika aktifitas masyarakat tersebut tidak ditangani dengan baik maka nasib mangrove, terumbu karang dan padang lamun di kawasan ini akan terjadi kerusakan seperti di pesisir pantai utara Pulau Jawa. Dari data lapangan diperoleh gambaran bahwa tingkat penggunaan lahan yang dikonversi dari tahun ke tahun terus mengalami peningkatan yang nantinya akan mengancam keberadaan hutan mangrove yang sampai saat ini dampaknya masih dirasakan, Jika kondisi seperti ini tidak ditangani secara serius oleh pemerintah akan mengalami degradasi hutan yang sangat parah seperti yang terjadi di Kalimantan, Cilacap dan Riau (Pramudji, at.al.1987). Berdasarkan berbagai fakta tersebut penulis merumuskan permasalahan pada penelitian ini yaitu: (1) Bagaimana megetahui persepsi masyarakat terhadap Pelestarian dan pemanfaatan lahan mangrove di sekitar Kawasan Konservasi Laut Daerah (KKLD) Gili Sulat - Gili Lawang. (2) Bagaimana mengetahui jenis mangrove yang terdapat di Kawasan Konservasi Laut Daerah (KKLD) Gili Sulat - Gili Lawang. (3) Bagaimana mengetahui dampak kerusakan lahan mangrove yang terdapat di Kawasan Konservasi Laut Daerah (KKLD) Gili Sulat-Gili Lawang. Tujuan penelitian ini adalah(1) Untuk mengetahui persepsi masyarakat terhadap lahan mangrove di Kawasan Konservasi Laut Daerah (KKLD) Gili Sulat- Gili Lawang (2) untuk mengetahui jenis mangrove di Kawasan Konservasi Laut Daerah (KKLD) Gili Sulat- Gili Lawang (3) untuk mengetahui dampak kerusakan mangrove di Kawasan Konservasi Laut Daerah (KKLD) Gili Sulat- Gili Lawang. METODEPENELITIAN

Penelitian ini dilaksanakan selama tiga bulan dari bulan April sampai bulan Juni 2019 . Data dianalisis secara deskriptif dengan menggunakan skala likert yaitu skala untuk mengukur persepsi dan sikap berbagai agen (sekelompok orang) terkait pemanfaatan dan konservasi lahan mangrove di Kawasan Konservasi Laut Daerah (KKLD) Gili Sulat-Gili Lawang, dengan memberikan skor yang mempunyai gradasi atau kontinum penilaian dari sangat setuju sampai sangat tidak setuju. Keterangan penilaiannya adalah : $5=$ sangat setuju (SS), 4 = setuju $(\mathrm{S}), 3=$ ragu-ragu $(\mathrm{RG}), 2$ = tidak setuju (TS), 1 = sangat tidak setuju (STS).Untuk mengetahui potensi jenis mangrove menggunakan metode jalur transek di 4 stasiun, dengan jarak antar transek 200 meter Data jenis mangrove yang terkumpul dianalisis secara deskriptif kualitatif dengan tujuan untuk menyajikan, mendeskripsikan atau menggambarkan, menguraikan secara jelas dan sistematis potensi jenis mangrove dan melakukan pengelompokan jenis mangrove yang disajikan dalam bentuk tabel. Tabel ini mengacu kepada penelitian Tamin 1992, Kunzman et al.1994 dan Kamal. 1995dan untuk mengetahui keanekaragaman jenis fauna air yang berasosiasi dengan lahan mangrove diperoleh dengan metode observasi nonpartisipan dan dianalisis dengan menggunakan analisis keragaman, keseragaman dan dominansi. 


\section{Gambar . Lokasi Penelitian (KKLD Gili Sulat dan Gili Lawang}

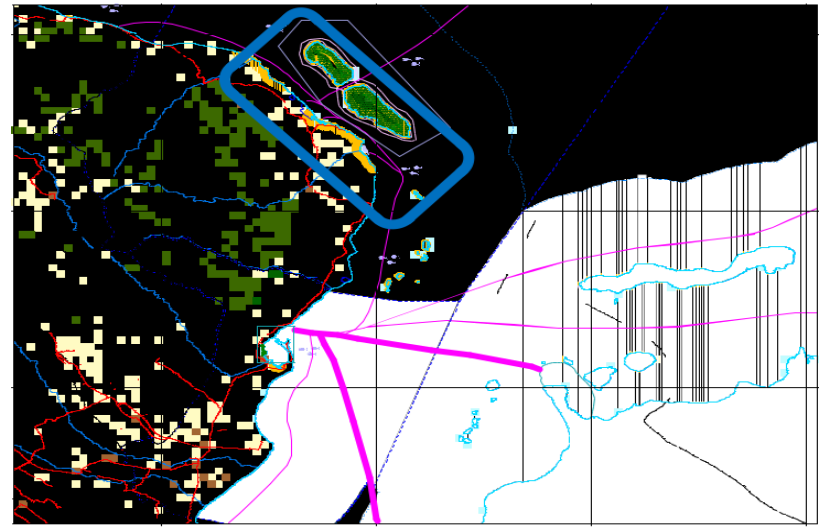

Sumber BAPEDA Provinsi Nusa Tenggara Barat 2006.

Keterangan:

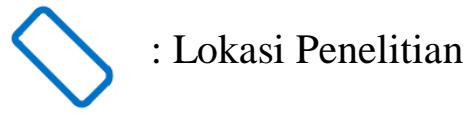

\section{HASIL DAN PEMBAHASAN}

\section{Persepsi Masyarakat}

Hasil jawaban dari responden untuk setiap butir pernyataan kemudian diberi skor berdasarkan nilai skala sikap model likert. Hasil kuisioner persepsi masyarakakatmenunjukkan sikap responden terhadap pelestarian dan konservasi lahan mangrove dari 60 responden, sangat setuju dengan nilai 261 atau $87 \%$,yang setuju dengan nilai sekitar 198 atau 66\%, raguragu dengan nilai 45 atau $15 \%$ dan tidak setuju dengan nilai sekitar 22 atau $0,7 \%$. Dengan demikian dari 60 orang responden masyarakat yang berprofesi sebagai nelayan menyatakan setuju terhadap pelestarian dan konservasi lahan mangrove di Kawasan Konservasi Laut Daerah (KKLD) Gili Sulat-Gili Lawang.

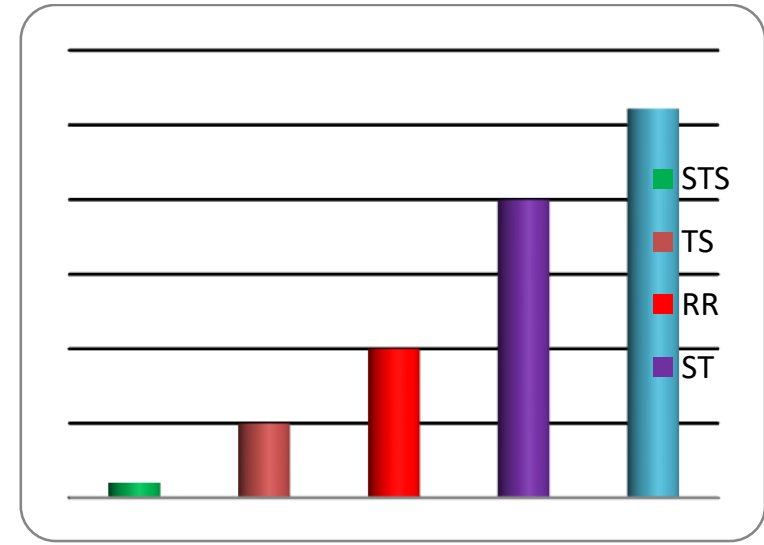

\section{Gambar:}

Grafik Tingkat Kesetujuan Masyarakat Tehadap Pelestarian dan Konservasi Lahan Mangrove.

Jadi berdasarkan data yang diperoleh dari 60 responden, maka rata-rata 198- 261-300 berada pada daerah setuju dan sangat setuju dan 10- 50 - 100 berada pada daerah sangat tidak setuju, tidak setuju dan ragu-ragu.

\section{Persepsi Pemerintah}

Sikap responden terhadap pelestarian dan pemanfaatan lahan mangrove dari 60 responden,sangat setuju dengan nilai 258 atau $86 \%$, setuju dengan total nilai sekitar 236 atau $78 \%$, ragu-ragu dengan nilai 28 atau $9 \%$ dan tidak setuju dengan total nilai sekitar 11 atau $3 \%$. Dengan demikian dari 60 orang responden Pemerintah (Dinas Kelautan Perikanan, Dinas Kehutanan) menyatakan setuju terhadap pelestarian dan pemanfaatan lahan mangrove di Kawasan Konservasi Laut Daerah (KKLD) Gili Sulat- Gili Lawang.

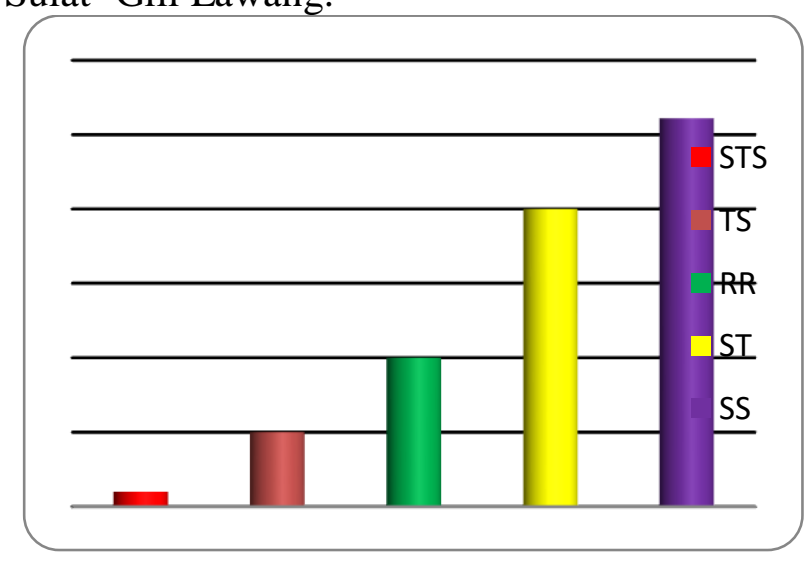

Gambar:

Grafik Kesetujuan Pemerintah Terhadap Pelestarian dan Konservasi Lahan Mangrove 
Berdasarkan data yang diperoleh dari 60 orang responden maka rata-rata 198 - $258-300$ berada pada daerah setuju dan sangat setuju dan 10- 28 - 100 berada pada daerah sangat tidak setuju, tidak setuju, dan ragu-ragu.

\section{Jenis Mangrove Di Kawasan Konservasi Laut} Daerah (KKLD) Gili Sulat-Gili Lawang

Penelitian ini dilaksanakan pada bulan Mei sampai Juni 2019 di bagi menjadi 4 stasiun yang berlokasi di Kawasan Konservasi Laut Daerah (KKLD) Gili Sulat- Gili Lawang Kabupaten Lombok Timur. Stasiun 1: Berada pada posisi $08^{0}-38^{0}$ LS (640) $117^{0}-44^{\circ}$ BT (869) dengan salinitas $30 \%$. Berdasarkan hasil identifikasi dan pengamatan lapangan terhadap mangrove yang tumbuh di stasiun I ditemukan beberapa jenis mangrove antara lain Rhizophora apiculata ,Lumnitzeraracemosa (combretaceae),Ceriops tagal (Rhizhoporaceae), Sonneratia alba,R. mucronata (Rhizophoraceae). Tanaman mangrove pada stasiun I diduduki oleh suku Rhizophoraceae yang terdapat pada zona tengah ke arah laut pada substrat berlumpur dengan jenis akar tunjang (tongkat). Dari suku Combretaceaeberada pada zona darat dengan tanahnya lempung berpasir dengan jenis akar papan, dan dari suku Sonneratiaceae berada pada zona darat dengan substrat lempung berpasir dengan akar cakar. Tabel.5.15 Stasiun 2: Berada pada posisi $08^{0}-38^{0} \mathrm{LS}(640) 117^{0}-44^{\circ}$ BT (869) dengan salinitas $35 \%$, Hasil identifikasi dan pengamatan terhadap tumbuhan mangrove yang berada di stasiun II ditemukan 2 jenis tumbuhan mangrove antara lain $: R$. stylosa (Rhizophoraceae) dan $R$. mucronata (Rhizophoraceae), Avicennia marina (Avicenniaceae). Tanaman mangrove pada stasiun II diduduki oleh suku Rhizophoraceae yang berada pada zona tengah ke arah laut pada substrat berlumpur dengan jenis akar tunjang (tongkat), dan dari suku Avicenniaceae berada pada zona darat dengan tanahnya lempung berpasir dengan jenis akar cakar. Stasiun III : Berada pada posisi $08^{0}-38^{0}$ LS (640) $117^{0}-44^{\circ}$ BT (869) dengan salinitas 35\% . Hasil identifikasi dan pengamatan terhadap tumbuhan mangrove yang berada di stasiun III ditemukan 2 jenis tumbuhan mangrove yaitu; $R$. mucronata (Rhizophoraceae), A. marina (Avicenniaceae). Tanaman mangrove pada stasiun III diduduki oleh suku Rhizophoraceae terdapat pada zona tengah ke arah laut pada substrat berlumpur dengan jenis akar tunjang (tongkat), dan dari suku Avicenniaceae berada pada zona darat dengan tanahnya lempung berpasir dengan jenis akar cakar. Stasiun IV : Berada pada posisi $08^{0}$ $38^{0}$ LS (640) $117^{0}-44^{\circ}$ BT (869) dengan salinitas $33 \%$. Hasil identifikasi dan pengamatan terhadap tumbuhan mangrove yang berada di stasiun IV ditemukan 2 jenis tumbuhan mangrove antara lain: $R$. mucronata (Rhizophoraceae) dan $R$. stylosa (Rhizophoraceae).Tanaman mangrove pada stasiun IV diduduki oleh suku Rhizophoraceae terdapat pada zona tengah ke arah laut pada substrat berlumpur dengan jenis akar tunjang (tongkat). Dari keseluruhan stasiun penelitian yaitu stasiun I, II, III dan IV untuk semua jenis mangrove diduduki oleh jenis $R$. mucronata, $R$. stylosa,R. apiculata, C.tegal, L. racemosa, dan A.marina hal ini didukung oleh pendapat Tomilson (1986), menyatakan bahwa jenis-jenis tersebut umum dijumpai di kawasan indomalesia (Indonesia dan Malaysia) yang merupakan pusat biogeografi jenis-jenis seperti Rhizophora, Sonneratia, Avicennia, Lumnitzera dan jenis lainnya. Steenis dalam Khirijon (1998) juga menyatakan bahwa pada umumnya struktur yang terbesar dari ekosistem mangrove di Indonesia diisi oleh suku Rhizophoraceae.

\section{Dampak Kerusakan Lahan Mangrove Terhadap Ikan dan Non Ikan di Lahan Mangrove Kawasan Konservasi Laut Daerah (KKLD) Gili Sulat-Gili Lawang.}

Kerusakan lahan mangrove akan berdampak kepada biota asosiasinya. Dampak kerusakan lahan mangrove terhadap biota yang berasosiasi didalamnya akan difokuskan pada jumlah hasil tangkapan individu spesies ikan dan non ikan di lahan mangrove. Dengan rusaknya lahan mangrove, maka spesies ikan dan non ikan yang berasosiasai dengan lahan mangrove akan beruaya mencari habitat baru yang bisa memberikan kebutuhan untuk mengasuh, 
mencari makan dan berkembang biak. Karena itu spesies ikan dan non ikan ini memperoleh makanan dari lahan mangrove baik secara langsung maupun tidak langsung. Pola adaptasi inilah yang menentukan ada tidaknya biota yang berasosiasi dengan lahan mangrove (ikan dan non ikan yang dikonsumsi), jika habitatnya bagus maka individu spesies ikan dan non ikan konsumsi akan banyak hidup didalamnya, begitu juga sebaliknya jika habitat rusak maka biota inipun akan berkurang bahkan hilang dari habitatnya. Berdasarkan hasil tangkapan yang diperoleh oleh masyarakat nelayan di lahan mangrove Kawasan Konservasi Laut Daerah (KKLD) Gili Sulat- Gili Lawang selama dua setengah bulan di lahan mangrove pada kondisi kerusakan lahan yang rendah memperlihatkan jumlah hasil tangkapan yang lebih besar untuk spesies ikan dengan jumlah 2.609 ekor dan non ikan dengan jumlah 4.678 ekor. Pada tingkat kerusakan lahan mangrove yang tinggi cenderung lebih sedikit dengan jumlah hasil tangkapan ikan 10.90 ekor dan non ikan 1.114 elor hal ini disebabkan ketersediaan pakan bagi biota laut yang ada di kawasan tersebut lebih banyak, karena didukung oleh lahan mangrove yang lebih luas tingkat kegiatan aktifitas masyarakat masih tergolong rendah dan secara langsung tidak terpengaruh oleh limbah pencemar . Pendapat ini didukung oleh Odum (1971), yang mengatakan bahwa peranan ekologis mangrove sebagai sumber energi rantai makanan biota perairan sangat penting. Ekosistem mangrove memberikan sumbangan bahan organik ke perairan mencapai 853 gram $/ \mathrm{m}^{2} /$ tahun. Kondisi kesuburan lahan mangrove akan sangat menentukan tingkat produktivitas biota yang ada didalamnya. Tumbuhan mangrove merupakan sumber makanan potensial, dalam berbagai bentuk bagi biota yang hidup di ekosistem mangrove. Berbeda dengan ekosisitem lainnya, komponen dasar dari rantai makan di lahan mangrove bukanlah hanya dari tumbuhan mangrove, melainkan serasah yang bersal dari mangrove dan material yang masuk ke ekosistem mangrove yang disebut dengan detritus
(Restu,2010). Analisis keragaman, keseragaman dan dominasi indek dapat digunakan untuk melihat kesetabilan suatu komunitas. Indeksindeks ini akan menunjukkan bagaimana kekayaan jenis ikan dalam komunitas serta keseimbangan setiap spesies. Suatu komunitas memiliki keseragaman tinggi jika semua jenis memiliki kelimpahan yang sama atau hampir sama. Jika hanya satu atau berbeda jenis saja yang melimpah maka tingkat keseragamannya rendah(Yuspardianto, 1988). Adapun famili dan spesies ikan dan non ikan yang dominan ditangkap adalah Famili siganidae merupakan famili yang paling dominan dengan jumlah tangkapan selama dua setengah bulan di lahan mangrove yang kondisi kerusakan lahan mangrove yang rendah sekitar 800 ekor dengan spesies beronang (siganus $s p$ ) dengan nilai keragaman 0,371, keseragaman0,209 dan indek dominansi 0,100. Jumlah hasil tangkapan di lahan mangrove kondisi kerusakan lahan yang tinggi untuk individu spesies ini adalah 1000 ekor selama dua setengah bulan dengan nilai keragaman 0,450, keseragaman 0,440 dan indeks dominansi 0441. Familli percessoses merupakan famili kedua yang dominan tertangkap di lahan mangrove yang kondisi kerusakan lahan mangrove yang rendah dengan jumlah tangkapan sekitar 600 ekor selama dua setengah bulan dengan spesies ikan belanak (Mugil labiosus) nilai keragaman 0,334, keseragaman 0,151 dan indeks dominansi 0,070 dan ikan bandeng (Chanos-chanos) dengan jumlah tangkapan selama dua setengah bulan sekitar 400 ekor dengan nilai keragaman 0,281, keseragaman 0,149 dan indeks dominansi 0,021. Di lahan mangrove yang kondisi kerusakan yang tinggi jumlah tangkapan sekitar 200 ekor selama dua setengah bulan untuk ikan belanak (Mugil labiosus) dengan nilai keragaman 0,315, keseragaman 0,199 dan indeks dominansi 0,039 dan ikan bandeng (Chanos-chanos) jumlah tangkapan sekitar 100 dengan nilai keragaman 0,217 , keseragaman 0,139 dan indeks dominansi 0,010 . Famili Serranidae merupakan famili ketiga yang tertangkap di lahan mangrove yang kondisi kerusakan lahan mangrove yang rendah, 
jumlah tangkapan sekitar 435 ekor selama dua setengah bulan dengan spesies ikan kerapu macan (Epinephelus merra) dengan nilai keragaman 0,300, keseragaman 0,188 dan indeks dominansi 0,030. Kerapu lumpur (Epinephelus tauvina) dengan hasil tangkapan selama dua setengah bulan 157 ekor dengan nilai keragaman 0,169, keseragaman 0,088 dan indeks dominanasi 0,005 dan kakap (Lates calcarifer) dengan jumlah 309 ekor dengan nilai keragaman 0,254 , keseragaman 0,150 , indek dominansi 0,017. Di lahan mangrove yang kondisi kerusakan lahan yang tinggi jumlah tangkapan sekitar 110 ekor untuk spesies kerapu lumpur (Epinephelus merra) dengan nilai keragaman 0,235 , keseragaman 0,145 dan indeks dominansi 0,012. untuk kerapu lumpur (Epinephelus merra) tidak ada. Ikan kakap (Lates calcarifer) dengan jumlah tangkapan sekitar 175 eor dengan nilai keragaman 0,294, keseragaman 0,182 dan indeks dominansi 0,026. Hasil tangkapan spesies non ikan di lahan mangrove yang kondisi kerusakan lahan mangrove yang rendah selama dua setengah bulan didominasi famili Portunidae dengan spesies kepiting (Scylla serrata)jumlah tangkapan sekitar 973 ekor dengan nilai keragaman 0,327, keseragaman 0,157dan indeks dominansi 0,139 dan rajungan (Portunus pelagicus) jumlah tangkapan sekitar 352 ekor dengan nilai keragaman 0,193, keseragaman 0,096 dan indeks dominansi 0,018. Sedangkan di lahan mangrove yang kondisi kerusakan lahan yang tinggi jumlah tangkapan spesies kepiting (Scylla serrata) 273 ekor dengan nilai keragaman 0,345, keseragaman 0,1165dan indeks dominansi 0,060, rajungan (Portunus pelagicus) 86 dengan nilai keragaman 0,198 keseragaman 0,095dan indeks dominansi 0,006. Famili yang kedua adalah Pelecypoda dengan spesies tiram bakau (Crassostrea cucullata) dengan jumlah tangkapan di lahan mangrove yang kondisi kerusakan lahan yang rendah selama dua setengah bulan sekitar 640 ekor dengan nilai keragaman0,130, keseragaman 0,135 dan indeks dominansi 0,060, kerang bulu (Anadara antiquata) jumlah tangkapan sekitar 590 ekor dengan nilai keragaman 0,125,keseragaman 0,129 dan indeks dominansi 0,051, kerang hijau (Mytilus viridis) jumlah tangkapan sekitar 760 ekor dengan nilai keragaman 0,141, keseragaman 0,146dan indeks dominansi 0,085 dan kerang darah (Anadara granosa) jumlah tangkapan sekitar 608 dengan nilai keragaman 0,127 , keseragaman 0,131 dan indeks dominansi 0,054. Pada lahan mangrove yang kondisi kerusakan lahan yang tinggi jumlah hasil tangkapan selama dua setengah bulan di peroleh tiram bakau (Crassostrea cucullata) jumlah tangkapan sekitar 109 ekor dengan nilai keragaman 0,218,keseragaman0,106 dan indeks dominansi 0,005, kerang bulu (Anadara antiquata) jumlah tangkapan sekitar 96 ekor dengan nilai keragaman 0,212,keseragaman 0,102 dan indeks dominansi 0,008, kerang hijau (Mytilus viridis) jumlah tangkapan sekitar 85 ekor dengan nilai keragaman 0,196, keseragaman 0,094dan indeks dominansi 0,006 dan kerang darah (Anadara granosa) jumlah tangkapan sekitar 119 ekor dengan nilai keragaman 0,236, keseragaman 0,114 dan indeks dominansi 0,011. Famili yang ketiga adalah Panaeidae dengan spesies udang windu (Penaeus monodon) dengan jumlah hasil tangkapan selama dua setengah bulan di lahan mangrove yang kondisi degradasi lahan yang rendah sekitar 375 ekor dengan nilai keragman 0,097, keseragaman 0,100 dan indeksdominansi 0,021 dan udang putih sekitar (Penaeus merguiensis) dengan jumlah tangkapan sekitar 380 ekor dengan nilai keragaman 0,098, keseragaman 0,101dan indeks dominansi 0,021. Di lahan mangrove yang kondisi degradasi lahan yang tinggi, udang windu (Penaeus monodon) hasil tangkapan selama tiga bulan sekitar 160 ekor dengan nilai keragaman 0.279, keseragaman 0,134 dan indeks dominansi 0,021 dan udang putih sekitar (Penaeus merguiensis) dengan jumlah tangkapan sekitar 195 ekor dengan nilai keragaman 0,305, keseragaman 0,146 dan indeks dominansi 0,031.Indeks keragaman hasil tangkapan ikan dan non ikan di lahan mangrove yang kondisi kerusakan lahan yang rendah menunjukkan nilai total keragaman untuk jenis ikan 1,682, nilai indeks tertinggi 
diperoleh spesies beronang (Siganus $s p$ ) dengan nilai 0,361 dan untuk non ikan total indek keragaman 1,138, nilai indeks tertinggi diperoleh nilai 0,327 dengan spesies kerang kepiting (Scylla serrata). Di lahan mangrove yang kondisi degradasi lahan yang tinggi total nilai keragaman untuk spesies ikan 1,402 dan non ikan 1,989, hasil tangkapan ikan dan non ikan menunjukan indeks keragaman tertinggi diperoleh spesies beronang (Siganus $s p$ ) dengan nilai indeks 0,355 , untuk non ikan spesies kepiting (Scylla serrata) dengan nilai indek 0,345 . Jika dilihat berdasarkan nilai keragaman yang dikemukakan oleh Sahannon dan Wienner (1968). Jika $\mathrm{H}<1$, maka indeks keragaman tergolong rendah. Di lokasi penelitian di Kawasan Konservasi Laut Daerah (KKLD) Gili Sulat - Gili Lawang dapat dinyatakan bahwa tingkat keragaman spesiesnya tergolong sedang di lahan mangrove pada kondisi kerusakan lahan yang rendah dan pada kondisi kerusakan lahan yang tinggi dimana $\mathrm{H}<\mathrm{I}$, maka keragaman spesiesnya tergolong rendah. Indeks keseragaman hasil tangkapan ikan dan non ikan di lahan mangrove kondisi kerusakan lahan yang rendah menunjukkan total nilai keseragaman tertinggi untuk jenis ikan 0,940 dan non ikan 0,968 . Indeks keseragaman paling tinggi adalah spesies beronang (Siganus $s p$ ) dengan indeks keseragaman 0,205 dan kepiting (Scylla serrata) dengan indek nilai keseragaman 0,157 . Di lahan mangrove kondisi kerusakan lahan yang tinggi untuk hasil tangkapan ikan total indek keseragaman tertinggi 0,868 dan non ikan 0,952. Indeks keseragaman tertinggi diperoleh spesies beronang (Siganus $s p$ ) dengan nilai 0,220 dan untuk non ikan diperoleh jenis kepiting (Scylla serrata) dengan nilai 0,165 .Mengacu kepada kriteria indeks nilai keseragaman yang dikemukakan oleh Shannon dan Wienner (1968), menyatakan apabila nilai $\mathrm{E}<0,6$, maka keseragaman sedang atau komunitas labil. Di lahan mangrove Kawasan Konservasi Laut Daerah (KKLD) Gili Sulat-Gili Lawang pada lahan mangrove kondisi kerusakan lahan yang rendah dan lahan mangrove kondisi kerusakan lahan mangrove yang tinggi dapat dinyatakan tingkat keseragaman jenis tergolong sedang dan komunitas dalam keadaan labil. Hal ini didukung oleh pendapat Budiman, (1992) dalam Pramudji, (2001) yang menyatakan intraksi hutan mangrove dan lingkungannya mampu menciptakan kondisi yang sesuai bagi berlangsungnya proses biologis beberapa organisme akuatik, daerah perairan hutan mangrove memberikan tempat berlangsungnya proses biologi bagi biota laut, apabila lingkungan relatif stabil dan tidak terlalu berfluktuatif tergantung pada priode tertentu serta tersedianya makanan bagi berbagai jenis biota. Salah satu penyebab utama terjadinya penurunan kualitas lahan mangrove akibat penggunaannya sebagai daerah pembuangan limbah, Degradasi yang terus-menerus yang kemudian diikuti oleh hilangnya ikan dan kerang-kerangan atau menurunnya daya dukung dari ekosistem(carrying capacity) (Dahuri, 2002) Indeks dominansi hasil tangkapan ikan dan non ikan di lahan mangrove kondisi kerusakan lahan yang rendah menunjukkan total indeks dominansi untuk spesies ikan 0,681 dan non ikan 0,428, indeks tertinggi diperoleh 0,090 untuk spesies beronag (Siganus sp) dan non ikan indek tertinggi diperoleh jenis spesies kepiting (Scylla serrata) dengan nilai 0,139. Di lahan mangrove yang kondisi kerusakan lahan yang tinggi hasil tangkapan ikan dan non ikan menunjukkan total untuk jenis ikan 0,268 dan non ikan 0,204, indeks dominansi tertinggi diperoleh jenis beronang (Siganus $s p$ ) dengan nilai 0,221, untuk non ikan jenis kepiting (Scylla serrata) dengan nilai 0,060. Mengacu kepada kriteria indeks dominansi Simpson dalam Odum, (1971) bahwa apabila nilai indeks dominansi berada pada kisaran 0-1 atau $\mathrm{D}=0$, maka tidak ada spesies yang mendominasi. Di lokasi penelitian di lahan mangrove yang berada pada kondisi kerusakan lahan yang rendah total indeks dominansi untuk jenis ikan 0,681 dan non ikan 0,428, indeks dominansi tertinggi spesies ikan beronang (Siganus $s p$ ) dengan indeks 0,90 dan non ikan dengan spesies kepiting (Scylla serrata) dengan nilai indek 0,139 dan pada daerah kerusakan lahan yang tinggi total indeks 
dominansi untuk jenis ikan 0,268 dan non ikan 0,204 , indeks tertinggi 0,221 untuk jenis ikan beronang (Siganus $s p$ ) non ikan indeks dominansi tertinggi 0,60 untuk jenis kepiting (Scylla serrata). Di lahan mangrove kondisi degradasi lahan yang rendah dan kondisi degradasi lahan yang tinggi Pesisir Desa Labuhan Sangoro dapat dinyatakan bahwa tidak ada spesies yang mendominasi yang menunjukkan bahwa dominansi spesies tergolong sedang. Menurut Dahuri et al. (2001), kondisi komunitas yang labil atau kurang stabil menunjukkan adanya sebaran individu-individu antar jenis yang tidak merata atau ada jenis yang dominan. Sedangkan komunitas dalam kondisi stabil karena individu-individu antar jenis relatif merata.

\section{Simpulan}

1. Persepsi masyarakat nelayan dan pemerintah menunjukkan sikap yang mendukung terhadap pelestarian dan konservasi lahan mangrove. Hal ini disebabkan dampak positip yang diterima jauh lebih besar dari dampak negatif dari adanya kerusakan lahan mangrove.

2. Potensi Jenis mangrove di Kawasan Konservasi Laut Daerah (KKLD) Gili SulatGili Lawang terdiri dari 7 (tujuh) jenis antara lain Rhizophora mucronata, $R$. apiculata, $R$. stylosa, Ceriops tagal, Avicennia marina, Sonneratia alba dan Lumnitzera racemosa. Potensi jenis mangrove di Kawasan Konservasi Laut Daerah (KKLD) Gili SulatGili Lawang terdapat 10 jenis dengan tumbuhan asosiasinya dan setelah dikonversi hanya ditemui 7 (tujuh) jenis.

3. Dampak pengrusakan lahan mangrove menyebabkan rusaknya habitat ikan dan non ikan di lahan mangrove yang diperoleh berdasarkan hasil tangkapan ikan dan non ikan di lahan mangrove pada kondisi kerusakan lahan yang rendah dan kondisi kerusakan lahan yang tinggi dalam jumlah individu spesies selama dua setengah bulan, tangkapan di lahan mangrove pada kondisi kerusakan lahan yang rendah dengan jumlah tangkapan ikan 2.700 ekor dan non ikan
4.678 ekor, lahan mangrove pada kondisi kerusakan lahan yang tinggi jumlah tangkapan ikan 2000 ekor dan non ikan 1.114 ekor. Hasil analisis keragaman, keseragaman dan dominansi spesies dalam kategori tingkat rendah dan sedang.

4. Kebijakan pengendalian kerusakan lahan mangrove yang sedang berjalan selama ini belum memadai terbukti terlihat masih adanya kerusakan dan deforestasi atau pengalihan fungsi hutan mangrove.

\section{Saran.}

1. Perlu upaya peningkatan kesadaran dan partisipasi masyarakat Sekitar Kawasan Konservasi Laut Daerah (KKLD) Gili SulaGili Lawang umumnya terhadap konservasi dan pemanfaatan lahan mangrove.

2. Perlu tindakan yang tegas dan jelas oleh pemerintah Kabupaten Lombok Timur dengan pemberian sangsi yang tegas bagi masyarakat ataupun yang dengan sengaja melakukan kegiatan pengrusakan lahan mangrove dengan pembuatan PERDA tentang pemanfaatan lahan mangrove di Kabupaten Lombok Timur.

3. Revitalisasi supremasi hukum harus terus ditegakkan agar para pelanggar kehutanan dapat segera diadili dengan sangsi yang setimpal sesuai dengan peraturan perundangundangan yang berlaku.

\section{DAFTAR PUSTAKA}

Ardhana, 2008. Pedoman Metode Penelitian Ekologis Sumberdaya Alam Hutan Buku Ajar Program Magister Pascasarjana Program Pemanfaatan Lahan Kering Universitas Udayana Denpasar.

2008. Metode dan Tehnik Degradasi Komposisi Biotik, Buku Ajar Program Pascasarjana Program Studi Ilmu Lingkungan Universitas Udayana Denpasar.

,2003. Pengelolaan Ekosistem Mangrove. Jurusan Biologi FMIPA Unud.

,2012. Ekologi Tumbuhan. Udayana University Press.

Bengen, D.G. 2001.Sinopsis Ekosistem dan Sumberdaya Alam Pesisir Dan Laut. 
Pusat Kajian Bengkulu Utara, Bengkulu. 2004. Jakarta.

BAPPEDA, 2010. Mangrove Nusa Tenggara Barat [Cited 2011 Desember 19] Avaiblable from: http://bappedanews. blogspot. com/2010/06/ keberadaankawasan-mangrove-di-ntb.html\#ixzz1 h3h4euqe.

BIMC,2003.Pengelolaan Hutan Mangrove Yang Berkelanjutan. Seminar Pengelolaan Hutan Mangrove Denpasar, Bali 8 September 2003, Mangrove Information Center.

Dahuri, R, J.Rais, S.P.Ginting, M.J.Sitepu.2004. Pengelolaan SumberdayaWilayah Pesisir dan Laut Secara Terpadu. Pradnya Paramita. Jakarta

DEPHUT,2001. Eksekutif Data Strategis Kehutanan. Departemen Kehutanan Badan Planologi Kehutanan Jakarta.

DEPDAGRI, 2009. Lampiran III, Peraturan Menteri Dalam Negeri Tahun 2007 Tentang Pedoman Penyusunan Dan Pendayagunaan Data Profil Desa Dan Kelurahan, Dirjen Pemberdayaan Masyarakat Dan Desa. Jakarta.

DKP, 2009.Laporan Riset Observasi Dan Kajian Pemanfaatan Kawasan Konsevasi Laut. Balai Riset Dan Observasi Kelautan Badan Riset Kelautan Dan Perikanan Departemen Kelautan Dan Perikanan. Jakarta.

Hilyana, S.2007. Jurnal Mitra Bahari Dirjen Pesisir dan Pulau-Pulau Kecil DKP, Jakarta Vol;1.3, Agustus-Nopember 2007. Hal : VII-X

Koentjaraningrat. 1983. Metode Penelitian Masyarakat. Jakarta, PT. Gramedia.

Laksmiwati, I. A. A. 1997. Perubahan Pengetahuan Sikap Dan Prilaku Kesehatan Reproduksi Remaja Di Kecamatan Denpasar Barat Kota Madya Denpasar (Tesis) Yogyakarta : Universitas Gajah Mada.

Nontji, A. 2005. Laut Nusantara Penerbit Rosdakarya Bandung.

Odum, E. P. 1971. Fundamental of ecology W.B.
Sounders. Co. Philadelpsshia

Restu, I. W, 2010. Modul V Ekosistem Mangrove (Mangrove Ecosystem) Jurusan Biologi MIPA Universitas Udayana.

Undang-Undang RI Nomor 27 Tahun 2007, tentang Pengelolaan Wilayah Pesisir Dan Pulau - Pulau Kecil. 